\title{
PHYTOCHEMICAL SCREENING OF ETHANOLIC EXTRACT OF WHOLE PLANT OF SIDA GLUTINOSA
}

\author{
GUDURU RAJESWARI ${ }^{1 *}$, SWARNA LATHA D ${ }^{2}$, CHANDRA SEKHAR KB ${ }^{3}$
}

\begin{abstract}
${ }^{1}$ Department of Pharmaceutical Sciences, Jawaharlal Nehru Technological University, Anantapuramu, Andhra Pradesh, India. ${ }^{2}$ Department of Pharmacognosy, Annamacharya College of Pharmacy, Rajampet, Andhra Pradesh, India. ${ }^{3}$ Department of Chemistry, Jawaharlal Nehru Technological University, Anantapuramu, Andhra Pradesh, India. Email: rajeswarim.pharm6@gmail.com
\end{abstract}

Received: 26 December 2019, Revised and Accepted: 03 February 2020

ABSTRACT

Objective: The aim of the present study is to screen for the phytochemical constituents which are of pharmacological importance present in the ethanolic extract of whole plant of Sida glutinosa (SG).

Methods: The ethanolic extract of the dried whole plant of SG is subjected to preliminary phytochemical screening which showed the presence of major phytoconstituents such as phenols, flavonoids, and alkaloids. The extract was screened for its antioxidant activity by 2,2-diphenyl-1picrylhydrazyl, hydroxyl radical, Iron (III) to Iron (II) reducing activity, and nitric oxide scavenging assay. Further, the ethanolic extract was subjected to fingerprinting technique high-pressure thin-layer chromatography (HPTLC). Reverse phase high-pressure liquid chromatography (Rp-HPLC) was performed to estimate the amount of total phenolics, flavonoids, and alkaloids quantitatively in isocratic mode.

Results: Phytochemical screening of the ethanolic extract of the plant showed the presence of pharmacologically important constituents such as alkaloids, flavonoids, phenolics, and terpenoids. The study also revealed the potential antioxidant activity of the extract with $\mathrm{IC}_{50}$ value. The extract fingerprinting through HPTLC revealed the presence of various phytoconstituents. Rp-HPLC showed $0.35 \pm 0.12 \mu \mathrm{g} / \mathrm{ml}$ of total phenolics, $0.0013 \pm 0.05 \mu \mathrm{g} / \mathrm{ml}$ of alkaloids, and $0.00081 \pm 0.08 \mu \mathrm{g} / \mathrm{ml}$ of flavonoids.

Conclusion: Scientific evaluation of SG which has therapeutic significance was carried out which is an important concept for the standardization of the plant-based drug. Further, there is a need for isolation and characterization of the lead molecules their systemic evaluation for its pharmacological activities.

Keywords: Sida glutinosa, In vitro antioxidant, High-pressure thin-layer chromatography, Reverse phase high-pressure liquid chromatography.

(C) 2020 The Authors. Published by Innovare Academic Sciences Pvt Ltd. This is an open access article under the CC BY license (http://creativecommons. org/licenses/by/4. 0/) DOI: http://dx.doi.org/10.22159/ajpcr.2020.v13i4.36697

\section{INTRODUCTION}

Sida glutinosa (SG) belongs to Malvaceae family. It is an annual herb and is found extensively grown in the region of Eastern and Southern regions of India and also extended into the region between South East Asia and Burma. The aerial parts and the roots of the plant are used in the treatment of a wide variety of ailments such as tuberculosis and rheumatidis $[1,2]$. In spite of its wide usage as an herbal treatment, there is no extensive research on the phytochemical screening, which is very important for the standardization of the drug. The literature survey revealed that nine different phytocompound had been isolated and characterized, among which three were proved to be an effective antioxidant drug [3,4]. From the methanolic extract of aerial parts of the plant showed the presence of a glucoside which is flavonoid [3]. The compound glutinosterone was reported and the studies also showed its role in the modification of some important liver marker enzymes [5]. In spite of its pharmacological importance, pharmacognostic standardization is lacking and in, present condition, the drugs are getting resistant by the human system and there is always growing need for the new drug which can cure the challenging diseases. As plant-based compounds are safe and efficient, there is a growing demand for proper research in this area. Therefore, the study deals with the standardization of drug by qualitative and quantitative analysis of total phenolics, flavonoids, and alkaloids which are of biological importance by reverse phase high-pressure chromatography (Rp-HPLC) in the ethanol extract of SG which is not done till date.

\section{METHODS}

\section{Chemicals and instrument}

The dried whole plant material was extracted using ethanol of analytical grade. For antioxidant activity DPPH of sigma grade, naphthyl ethylene diamine dihydrochloride gifted, ascorbic acid from HiMedia, deoxyribose of sigma grade is used. DMSO of analytical grade, EDTA of Sd fines are used in the phytochemical screening. High-performance thin-layer chromatography (HPTLC), CAMAG, Switzerland, and software WinCATS 4 software are used. Supercon liquid chromatography-mass spectrometer was done by Shimadzu 2010A model. Fourier-transform infrared spectra were got from $\mathrm{KBr}$ discs and an instrument used Thermo Nicolet Id5, nuclear magnetic resonance (NMR), i.e., C-NMR and H-NMR by Bruker NMR with $500 \mathrm{MHz}$ using TMS as internal standard. For column chromatography silica mesh size 60-120 Merck and Silica gel G, Merck for thin-layer chromatography (TLC) was used.

\section{Collection of plant material}

The fresh and healthy whole plant material of SG was collected from Eastern Ghats of Tirupati, Andhra Pradesh, India. The plant material was identified from Botany professor Mr. Madhavan Chetty and the specimen is preserved in the herbarium in the Department of Botany, SV University, Tirupati, with the herbarium number being 1035 .

\section{Preliminary phytochemical screening}

Extractive value

Ethanolic soluble extractive value and water-soluble extractive value of air-dried coarse powder of plant materials SG are determined. The 
percentage of ethanolic soluble extractive value and water-soluble extractive value with reference to air-dried material was calculated and the values are recorded.

\section{Determination of moisture content}

The difference in the weight the percentage of loss on drying with reference to the air-dried drug was calculated [6-8].

\section{Ultraviolet (UV) study}

A small quantity of dried powder of the plant materials was placed on the grease-free microscopic slide and treated with 1-2 drops of chemical reagents such as $1 \mathrm{~N} \mathrm{HCl}, 1 \mathrm{~N} \mathrm{HNO}_{3}, 1 \mathrm{~N} \mathrm{H}_{2} \mathrm{SO}_{4}, 1 \mathrm{~N} \mathrm{NaOH}$, alcoholic $\mathrm{NaOH}$, $1 \mathrm{KOH}$, alcoholic $\mathrm{KOH}$, and ammonia separately with gentle tilting. The slides were placed in the ultraviolet viewer chamber and viewed in daylight, short (254 nm) and long (365 nm) UV radiation and the color changes of the powdered drug when treated with different chemical reagents were recorded based on different chemical constituents [9].

\section{Preliminary phytochemical screening}

Five kilogram of the healthy plant material of SG was shade dried and finely ground into a coarse powder. This coarse powder was subjected for Soxhlet extraction process using ethanol. The extraction was continued until the solution in the siphon was colorless. Then, the ethanolic extract was subjected to rotary evaporation, where the solvent was recovered leaving behind ethanolic extract. Ethanolic extracts of the SG were subjected to a preliminary phytochemical screening. The extracts were screened for the presence of alkaloids, carbohydrates, glycosides, saponins, phytosterols, fixed oils and fats, resins, tannins, phenols, flavonoids, proteins and amino acids, terpenes and terpenoids, gums and mucilage, and lignin $[10,11]$

\section{In vitro antioxidant activity}

Plants play an important role in scavenging the free radicals and thereby proving as an potent antioxidant. In this study, the ethanolic extract of SG was evaluated for their potent antioxidant activity using four important models.

a. Iron (III) to Iron (II) reducing activity

The ability of the extracts and isolated compounds to reduce iron III was assessed [12]. The reduction potential was measured spectrophotometrically at $700 \mathrm{~nm}$. The results were expressed as ascorbic acid equivalents in $\mathrm{mg}$ of ascorbic acid per $\mathrm{g}$ of extract.

b. Hydroxyl radical scavenging activity

Hydroxyl radical scavenging was carried out by measuring the competition between deoxyribose and the extracts and isolated compounds for hydroxyl radicals generated from the $\mathrm{Fe} 3+$ / Ascorbate/EDTA $/ \mathrm{H}_{2} \mathrm{O}_{2}$ system a method carried [12]. Butylated hydroxytoluene was taken as the standard.

c. Diphenyl picrylhydrazyl radical scavenging assay

The DPPH scavenging assay was carried out to the test extracts and isolated compounds [13]. The scavenging property is read at $517 \mathrm{~nm}$ and inhibition of diphenyl picrylhydrazyl radical was calculated.

d. Nitric oxide scavenging activity

Nitrite ions generated from sodium nitroprusside react with the Griess reagent to form a purple azo dye. In the presence of the test components, likely to be scavengers, the amount of nitrites will decrease. The degree of decrease in the formation of purple azo dye will reflect the extent of scavenging [14]. The nitric oxide scavenging assay was assessed for all the test extracts and isolated compounds taking gallic acid as standard.

\section{HPTLC}

HPTLC was performed on silica gel $60 \mathrm{~F} 254(10 \mathrm{~cm} \times 10 \mathrm{~cm} ; 0.25 \mathrm{~mm}$ layer thickness; Merck). SG extract prepared in $10 \mathrm{ml}$ volumetric flask by taking $250 \mathrm{mg}$ of the extract and diluting with ethanol the concentration was $25 \mathrm{mg} / \mathrm{ml}$ and filtered through a $0.45 \mu$ syringe filter from this 4,6 , and $12 \mathrm{mg} / \mathrm{ml}$ concentrations were subjected to HPTLC (CAMAG, Switzerland) analysis. All these dilutions were spotted on a silica gel 60F254 (Merck, Darmstadt, Germany) TLC plate. The plate was air-dried and then developed using the solvent system hexane: chloroform:methanol (3:3.5:3.5 v/v) as mobile phase in a CAMAG twin trough glass chamber previously saturated with mobile phase vapor for $20 \mathrm{~min}$. After developing the plate, it was dried at $65^{\circ} \mathrm{C}$ for $2 \mathrm{~min}$ and then it was scanned using Camag Scanner 3 (CAMAG, Switzerland) at 254 and $365 \mathrm{~nm}$ using WinCATS 4 software [15].

Determination of total phenolics, flavonoids, and alkaloids by Rp-HPLC

\section{Total phenolics [16]}

Mobile phase was prepared by mixing methanol: water (60:40); $\mathrm{pH}$ was adjusted to 3.1 with orthophosphoric acid. This solution was filtered using a $0.45 \mu$ Millipore filter paper and was sonicated for $10 \mathrm{~min}$. The total volume of the mobile phase prepared was $300 \mathrm{ml}$

Standard: The standard concentration of gallic acid taken was $100 \mu \mathrm{g} / \mathrm{ml}$.

Sample preparation: To $5 \mathrm{mg}$ SG extracts, $5 \mathrm{ml}$ of ethanol was added. The solution was vortexed for $5 \mathrm{~min}$. The sample was filtered using $0.45 \mu$ Millipore filters. Twenty microliter of the sample was injected in the HPLC system.

Wavelength: $254 \mathrm{~nm}$.

\section{Flavonoids [17]}

With a slight modification, mobile phase was prepared by mixing methanol: $0.2 \%$ acetic acid pH 3.5 (50:50). This solution was filtered using a $0.45 \mu$ Millipore filter paper and was sonicated for $10 \mathrm{~min}$. The total volume of the mobile phase prepared was $300 \mathrm{ml}$.

Standard: The standard concentration of quercetin acid taken was $100 \mu \mathrm{g} / \mathrm{ml}$.

Sample preparation: To $5 \mathrm{mg}$ SG extracts, $5 \mathrm{ml}$ of ethanol was added. The solution was vortexed for $5 \mathrm{~min}$. The sample was filtered using $0.45 \mu$ Millipore filters. Twenty microliter of the sample was injected in the HPLC system.

Wavelength: $254 \mathrm{~nm}$.

\section{Alkaloids [18]}

Mobile phase was prepared by mixing methanol: water (90:10). This solution was filtered using a $0.45 \mu$ Millipore filter paper and was sonicated for $10 \mathrm{~min}$. The total volume of the mobile phase prepared was $300 \mathrm{ml}$

Standard: The standard concentration of berberine taken was $100 \mu \mathrm{g} / \mathrm{ml}$.

Sample preparation: To $5 \mathrm{mg}$ SG extracts, $5 \mathrm{ml}$ of ethanol was added. The solution was vortexed for $5 \mathrm{~min}$. The sample was filtered using $0.45 \mu$ Millipore filters. Twenty microliter of the sample was injected in the HPLC system.

Wavelength: $220 \mathrm{~nm}$.

\begin{tabular}{ll}
\hline \multicolumn{2}{l}{ Common optimized chromatographic conditions } \\
\hline Detector & Shimadzu SPD 10A UV-vis, Japan \\
Pump & Shimadzu LC-10ATVP, Japan \\
Software & Baseline chromatography data system N2000 \\
Injection valve & $7725 \mathrm{i}$ Rheodyne $20 \mu \mathrm{ll}$, USA \\
Syringe & $50 \mu \mathrm{l}$ Hamilton, Switzerland \\
Column & Phenomenex Gemini-NX-5 $\mu \mathrm{m}$ C18(2) $110 \AA$, \\
& LC Column $250 \times 4.6 \mathrm{~mm}, \mathrm{Ea}$ \\
Part no. & $00 \mathrm{G}-4041-\mathrm{EO}$ \\
Dimensions & $250 \times 4.6 \mathrm{~mm} \mathrm{ID}$ \\
Flow rate & $1 \mathrm{ml} / \mathrm{min}$ \\
\hline
\end{tabular}




\section{RESULTS}

\section{Extractive values}

The coarse plant material of SG was subjected for the determination of moisture content or loss on drying; it was found that the percentage of loss on drying was just 15. If the moisture-holding capacity of the drug was high, it would lead to the deterioration of the plant material. As in this case, the loss on drying was negligible; it ensures the stability of the drug. The coarse plant material showed the alcoholic extractive value $14 \%$ and water extractive value as $6 \%$, respectively, suggested that most of the phytoconstituents which are of clinical importance are extracted with ethanol compared to water (Table 1).

\section{Fluorescent study of crude extract of SG}

The chromophores help as a major parameter in pharmacognosy for the standardization of the drug. The results are summarized in Tables 2 and 3.

\section{Preliminary phytochemical screening of ethanolic extract of SG}

The plant material was subjected to Soxhlet extraction using ethanol. The ethanolic extract was subjected for the qualitative determination of phytoconstituents. The study revealed the presence of alkaloids, glycosides, phenols, tannins, terpenoids, and flavonoids which are of pharmacological importance (Table 4).

Table 1: Extractive values

\begin{tabular}{lll}
\hline Sl. no. & Parameter & SG (\%) \\
\hline 1. & Moisture & 15 \\
2. & Alcohol-soluble extractive & 14 \\
3. & Water-soluble extractive & 6 \\
\hline SG: Sida glutinosa & &
\end{tabular}

Table 2: Fluorescent study of crude extract of SG

\begin{tabular}{|c|c|c|c|c|}
\hline \multirow{2}{*}{$\begin{array}{l}\text { Sl. } \\
\text { no. }\end{array}$} & \multirow[t]{2}{*}{ Extract } & \multirow[t]{2}{*}{ Daylight } & \multicolumn{2}{|l|}{ UV light } \\
\hline & & & Short $254 \mathrm{~nm}$ & Long $365 \mathrm{~nm}$ \\
\hline 1. & Ethanol & Lemon yellow & Light green & Mustard yellow pale \\
\hline
\end{tabular}

Table 3: Fluorescent study of crude extract of SG

\begin{tabular}{|c|c|c|c|c|}
\hline \multirow[t]{2}{*}{ Sl. no. } & \multirow[t]{2}{*}{ Treatment } & \multirow[t]{2}{*}{ Day light } & \multicolumn{2}{|l|}{ UV light } \\
\hline & & & $\begin{array}{l}\text { Short } \\
254 \mathrm{~nm}\end{array}$ & $\begin{array}{l}\text { Long } 365 \\
\mathrm{~nm}\end{array}$ \\
\hline 1. & Powder & Green & $\begin{array}{l}\text { Dark } \\
\text { brown }\end{array}$ & $\begin{array}{l}\text { Dark } \\
\text { brown }\end{array}$ \\
\hline 2. & Powder $+\mathrm{H}_{2} \mathrm{O}$ & Dark green & $\begin{array}{l}\text { Dark } \\
\text { brown }\end{array}$ & Green \\
\hline 3. & Powder+1N HCl & Brownish-green & $\begin{array}{l}\text { Dark } \\
\text { brown }\end{array}$ & $\begin{array}{l}\text { Light } \\
\text { green }\end{array}$ \\
\hline 4. & Powder+1 $\mathrm{N} \mathrm{HNO}_{3}$ & Brown & $\begin{array}{l}\text { Dark } \\
\text { brown }\end{array}$ & $\begin{array}{l}\text { Dark } \\
\text { green }\end{array}$ \\
\hline 5. & Powder+1 $\mathrm{N} \mathrm{H}_{2} \mathrm{SO}_{4}$ & Pale brown & $\begin{array}{l}\text { Dark } \\
\text { brown }\end{array}$ & $\begin{array}{l}\text { Dark } \\
\text { green }\end{array}$ \\
\hline 6. & Powder+1N NaOH & Dark green & $\begin{array}{l}\text { Dark } \\
\text { brown }\end{array}$ & $\begin{array}{l}\text { Mustard } \\
\text { yellow }\end{array}$ \\
\hline 7. & Powder+Alc. $\mathrm{NaOH}$ & Pale green & $\begin{array}{l}\text { Dark } \\
\text { brown }\end{array}$ & $\begin{array}{l}\text { Mustard } \\
\text { yellow }\end{array}$ \\
\hline 8. & Powder+1N KOH & Dark green & $\begin{array}{l}\text { Dark } \\
\text { brown }\end{array}$ & $\begin{array}{l}\text { Dark } \\
\text { green }\end{array}$ \\
\hline 9. & Powder+Alc. $\mathrm{KOH}$ & Dark green & $\begin{array}{l}\text { Dark } \\
\text { brown }\end{array}$ & $\begin{array}{l}\text { Yellowish- } \\
\text { green }\end{array}$ \\
\hline 10. & Powder+Ammonia & Dark green & $\begin{array}{l}\text { Dark } \\
\text { brown }\end{array}$ & Green \\
\hline
\end{tabular}

SG: Sida glutinosa, UV: Ultraviolet

\section{Antioxidant activity}

The ethanolic extract of SG was assessed for its anti-oxidant activity. The $\mathrm{IC}_{50}$ values for standard ascorbic acid and extract in DPPH model showed $82.88 \pm 0.52$ and $238.97 \pm 0.68 \mu \mathrm{g} / \mathrm{ml}, \mathrm{IC}_{50}$ values in hydroxyl radical standard butylated hydroxytoluene and the extract is $39.61 \pm 0.36$ and $61.99 \pm 0.37 \mu \mathrm{g} / \mathrm{ml}$, and in nitric oxide model standard gallic acid and extract showed $\mathrm{IC}_{50}$ values $145.66 \pm 0.58$ and $423.65 \pm 0.56 \mu \mathrm{g} / \mathrm{ml}$ respectively. The values are summarized in Table 5 and Graphs 1-3. The extract also showed the reducing activity (Graph 4). This indicates that the plant material is a good antioxidant.

\section{HPTLC}

Standarization of drug needs many validation procedure among which on once such method is high performance thin iayer chromatography

Table 4: Preliminary phytochemical screening of ethanolic extract of SG

\begin{tabular}{|c|c|c|}
\hline Sl. no. & Test & SG \\
\hline \multirow[t]{3}{*}{1.} & Detection of alkaloids & \\
\hline & Hager's test & +++ \\
\hline & Dragendorff test & + \\
\hline \multirow[t]{4}{*}{2.} & Detection of carbohydrates & \\
\hline & Molisch's test & - \\
\hline & Benedict's test & - \\
\hline & Barfoed's test & - \\
\hline \multirow[t]{3}{*}{3.} & Detection of glycosides & \\
\hline & Modified Borntrager's test & +++ \\
\hline & Legal's test & - \\
\hline \multirow[t]{3}{*}{4.} & Detection of phytosterols & \\
\hline & Salkowski's test & + \\
\hline & Liebermann-Burchard's test & - \\
\hline \multirow[t]{2}{*}{5.} & Detection of phenols & \\
\hline & Ferric chloride test & +++ \\
\hline \multirow[t]{3}{*}{6.} & Detection of tannins & \\
\hline & Gelatin test & +++ \\
\hline & Lead acetate test & ++ \\
\hline \multirow[t]{5}{*}{7.} & Detection of flavonoids & \\
\hline & Alkaline reagent test & +++ \\
\hline & Lead acetate test & +++ \\
\hline & Zinc-hydrochloric acid test & +++ \\
\hline & Shinoda test & +++ \\
\hline \multirow[t]{2}{*}{8.} & Detection of proteins and amino acids & \\
\hline & Ninhydrin test & - \\
\hline \multirow[t]{2}{*}{9.} & Detection of terpenes and terpenoids & \\
\hline & Copper acetate test & +++ \\
\hline \multirow[t]{2}{*}{10.} & Detection of saponins & \\
\hline & Froth test & + \\
\hline \multirow[t]{2}{*}{11.} & Detection of oil and fat & \\
\hline & Stain test & - \\
\hline \multirow[t]{3}{*}{12.} & Detection of resins & \\
\hline & Acetone water test & ++ \\
\hline & Gums and mucilage & - \\
\hline 13. & Detection of lignin & + \\
\hline
\end{tabular}

+++: Strong color intensity, ++: Medium color intensity, +: Weak color intensity, -Not detected, SG: Sida glutinosa

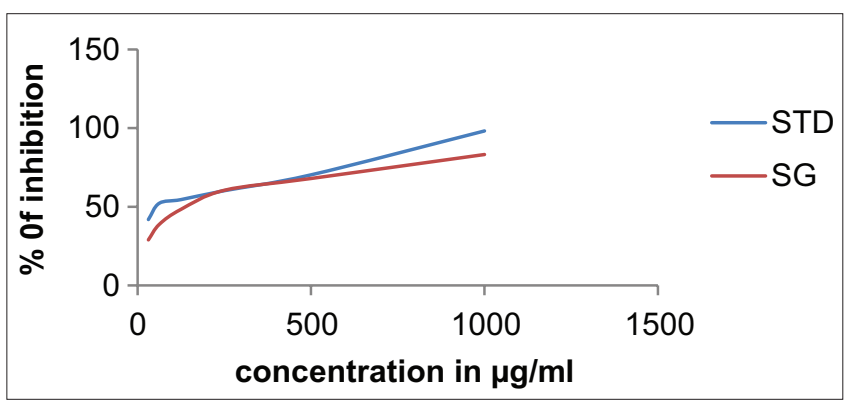

Graph 1: Antioxidant activity by 2,2-diphenyl-1-picrylhydrazyl method 
or HPTLC. In this study, ethanol extract of SG is subjected to HPTLC. The extract fingerprinting through HPTLC revealed the presence of various phytoconstituents at near UV and far UV radiations which are of pharmacological importance (Figs. 1-5)

\section{Estimation of total phenols, alkaloids, and flavonoids}

Here, the amount of total phenols and flavonoids was estimated quantitatively by Rp-HPLC using column Phenomenex Gemini-NX-5 $\mu \mathrm{m}$ C18 (2) $110 \AA$, LC Column $250 \times 4.6 \mathrm{~mm}$. The elution being isocratic system. For alkaloids mobile phase was methanol: water (90:10), flow rate $1 \mathrm{ml} / \mathrm{min}$, absorption maxima $220 \mathrm{~nm}$ was fixed (Figs. 6-8). Flavonoids was estimated by using mobile phase methanol: $0.2 \%$ acetic acid at $\mathrm{pH} 3.5$ (50:50), flow rate $1 \mathrm{ml} / \mathrm{min}$, and absorption maxima 254 nm (Figs. 9-11). For estimation of total phenolics parameters such as mobile phase methanol: water (60:40), flow rate $1 \mathrm{ml} / \mathrm{min}$, absorption maxima $254 \mathrm{~nm}$ was adjusted (Figs. 12-14). Blank chromatogram did

Table 5: $\mathrm{IC}_{50}$ in $\mu \mathrm{g} / \mathrm{ml}$

\begin{tabular}{llll}
\hline $\mathbf{I C}_{50}$ in $\boldsymbol{\mu g} / \mathbf{m l}$ & & & \\
\hline Sample & DPPH & Hydroxyl radical & Nitric oxide \\
Standard & $82.88 \pm 0.52$ & $39.61 \pm 0.36$ & $145.66 \pm 0.58$ \\
Sida glutinosa & $238.97 \pm 0.68$ & $61.99 \pm 0.37$ & $423.65 \pm 0.56$ \\
\hline
\end{tabular}

All the values are expressed as mean \pm SEM. SEM: Standard error of mean DPPH: 2,2-diphenyl-1-picrylhydrazyl

Table 6: Content of phytoconstituents in the ethanolic extract of SG in $\mu \mathrm{g} / \mathrm{ml}$

\begin{tabular}{ll}
\hline Phytoconstituents & $\begin{array}{l}\text { Content of phytoconstituents in the } \\
\text { ethanolic extract of SG in mg/g dry weight }\end{array}$ \\
Phenolics & $35.8 \pm 0.12$ in mgGAE/g dry weight \\
Alkaloids & $0.13 \pm 0.05 \mathrm{mg}$ Ber/g dry weight \\
Flavonoids & $0.0805 \pm 0.08 \mathrm{mgQE} / \mathrm{g}$ dry weight \\
\hline
\end{tabular}

All the values are expressed for the measurement of three experiments as mean \pm SEM. SEM: Standard error of mean, SG: Sida glutinosa

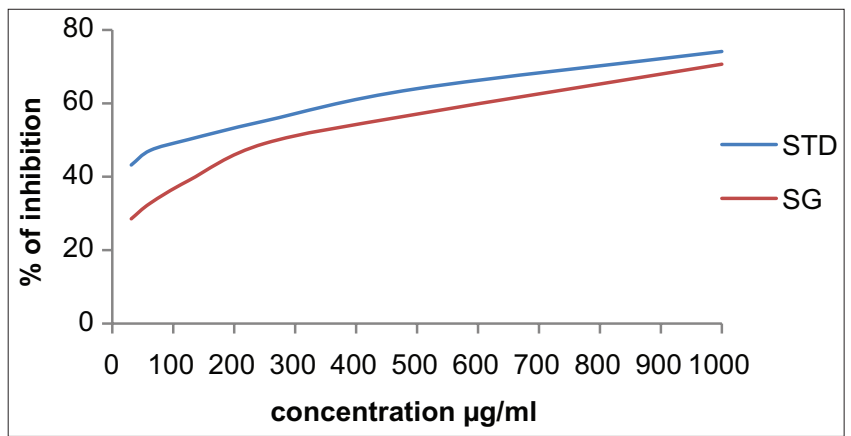

Graph 2: Antioxidant activity by nitric oxide method

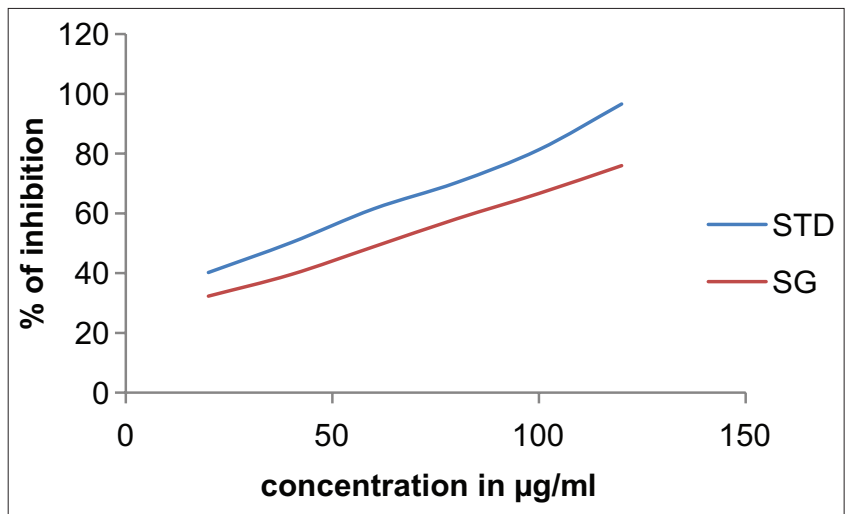

Graph 3: Antioxidant activity by hydroxyl radical method not show any kind of contaminants. The Rt values of the standards were compared with its same Rt values in the sample chromatogram under same chromatographic conditions, area of both standard and samples was noted. The concentration of total phenolics, flavonoids, and alkaloids was calculated and is summarized in Table 6 .

\section{DISCUSSION}

Determination of the physical and chemical parameters in the plant material is very important for the standardization of the drug. Therefore, in this paper attempt was done to standardize some of the chemical parameters. The screening of phytochemicals in might help in getting a lead pharmacological molecule which can be used as drug [19]. The study revealed the presence of major phytoconstituents which justified that the plant contains many biological active principles. Similar type of observation was made with aqueous extract of leaves of different species [20]. Many chemical compounds present in the plant materials will behave as chromophores. These chromophores on reacting with the chemical reagent give out characteristic colors when exposed under the UV light. The qualitative screening of phytochemicals in methanolic extract of SG was not completely reported in Murthy et al. [21] and in the present study, this investigation has been covered in the ethanolic extract of SG.

Reactive oxygen species which are produced in a cell by various metabolic processes are responsible for the damage of DNA and to bring abnormality in the cell. It is reported that the plant produces some important phytoconstituents which neutralize the effect of these reactive oxygen species. Reports of antioxidant activity in the methanolic extract of SG by DPPH model are reported [21] and chloroform extract of different species of same genus Sida acuta was reported [22] and hence proving that genus and its specific epithet family Malvaceae are having good antioxidant property. Therefore, in the present, the scavenging properties of the plant extract are explored to study its antioxidant nature. $\mathrm{IC}_{50}$ values of plant extract are more than the standard $\mathrm{IC}_{50}$ values. Percentage of inhibition in

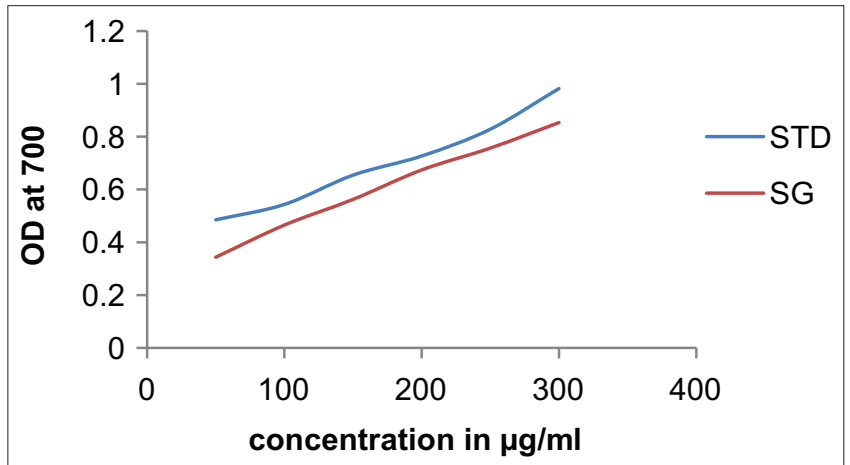

Graph 4: Antioxidant activity by ferric-reducing/antioxidant power method

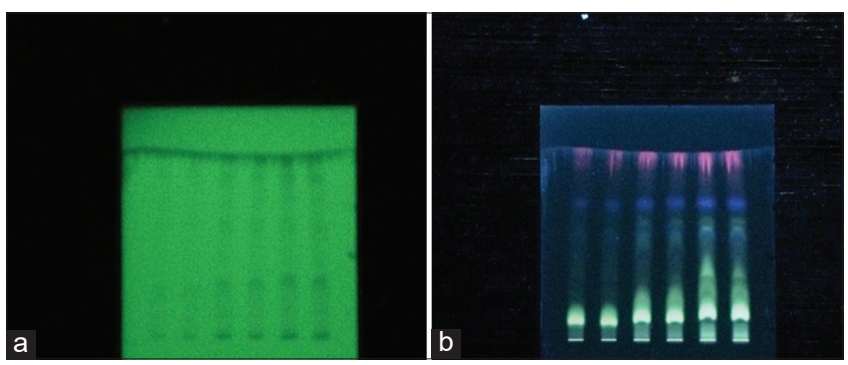

Fig. 1: (a) High-performance thin-layer chromatography chromatogram plate of Sida glutinosa extracts $(256 \mathrm{~nm})$.

(b) High-performance thin-layer chromatography chromatogram plate of Sida glutinosa extract (366 nm) 


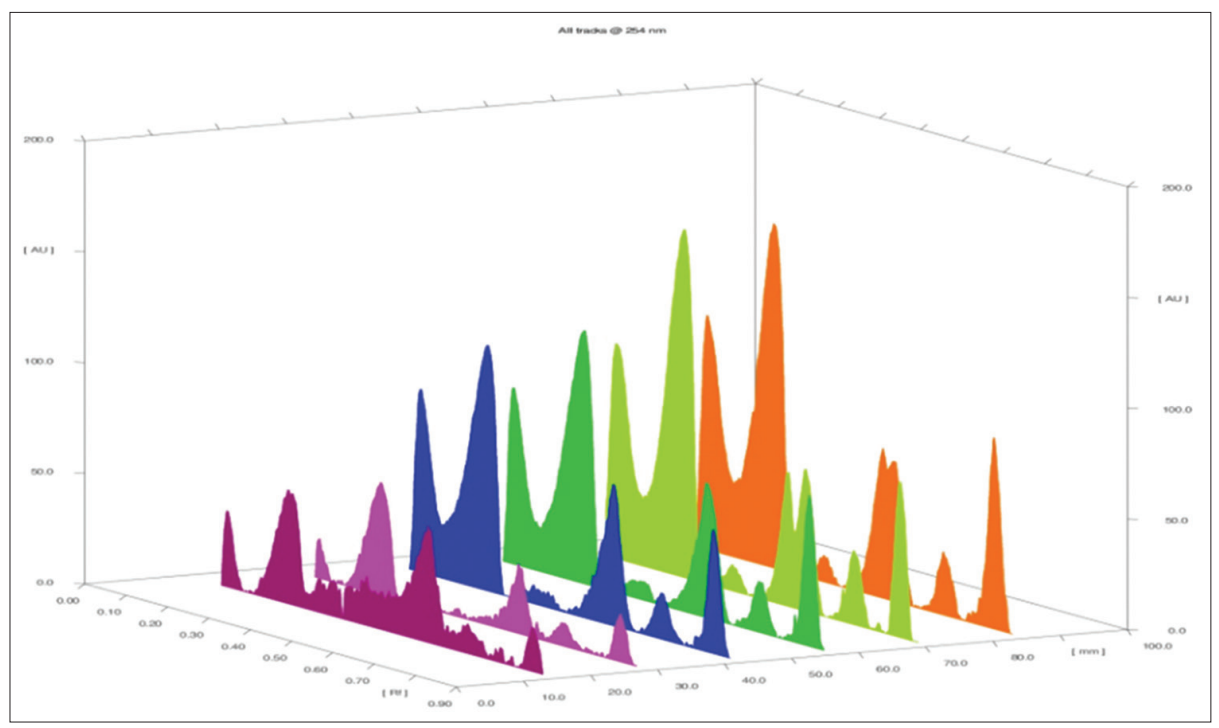

Fig. 2: Overlay spectra of Sida glutinosa extract at $254 \mathrm{~nm}$

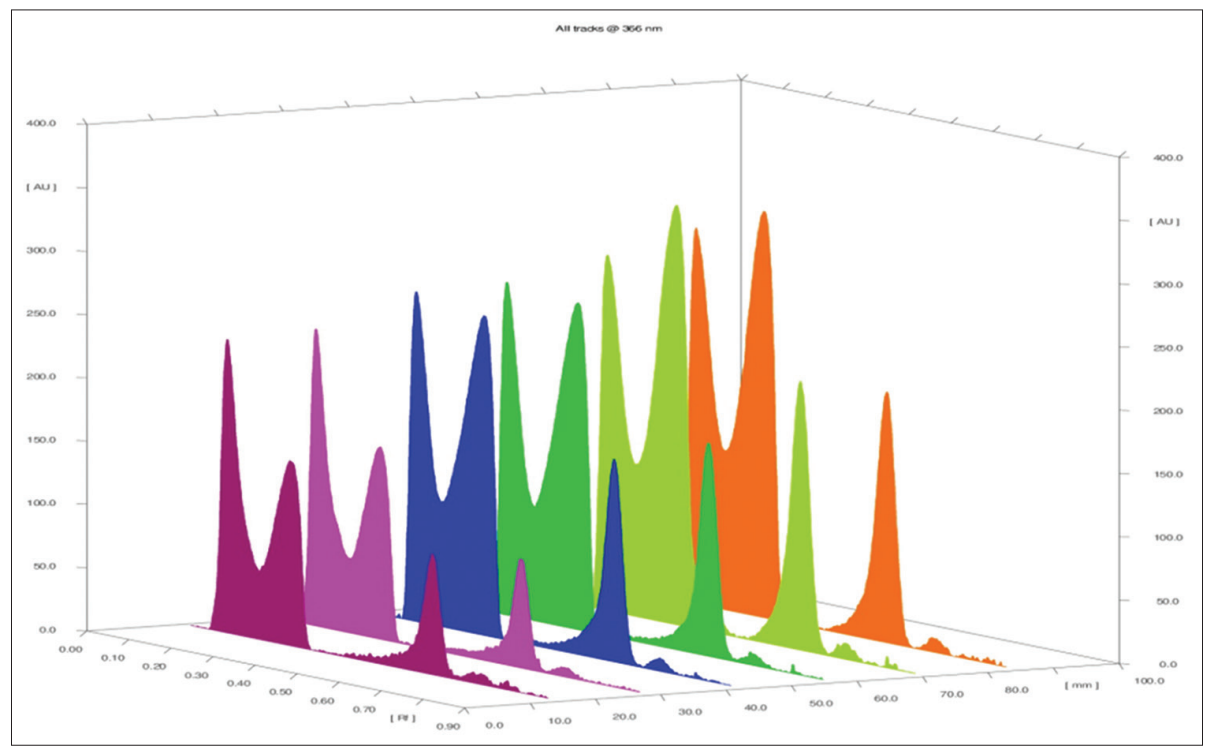

Fig. 3: Overlay spectra of Sida glutinosa extract at $266 \mathrm{~nm}$

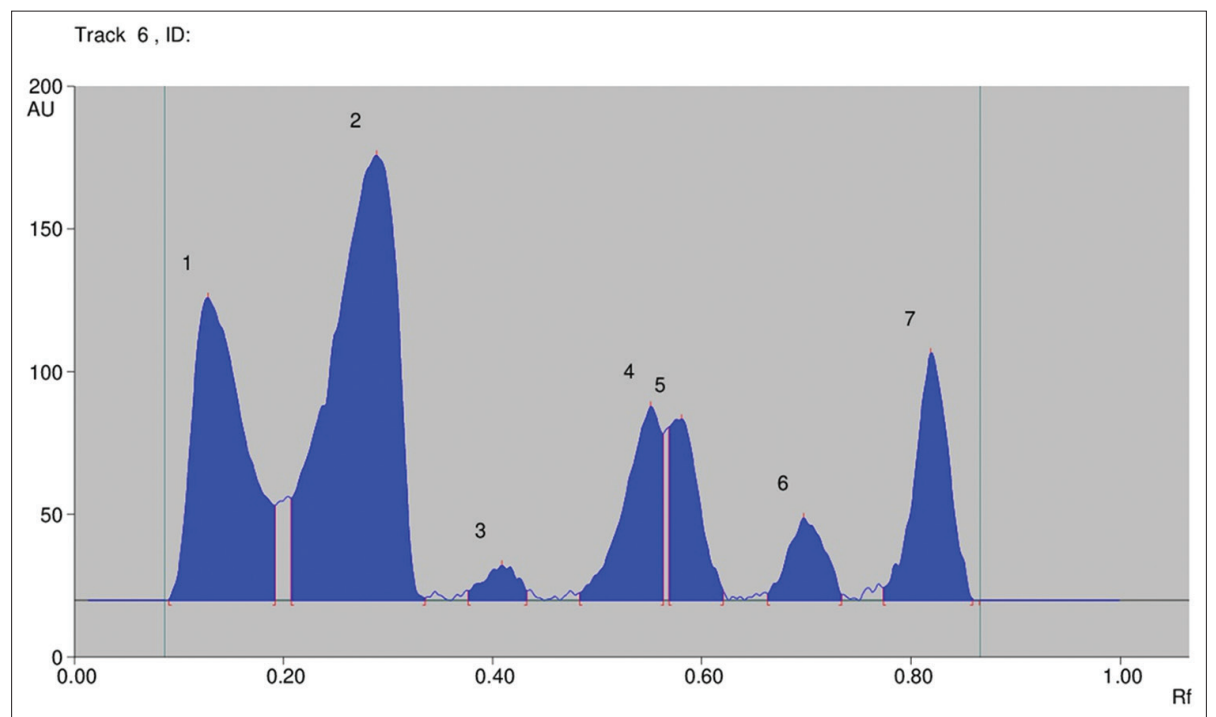

Fig. 4: High-performance thin-layer chromatography densitometric chromatogram of Sida glutinosa extract at $254 \mathrm{~nm}$ 


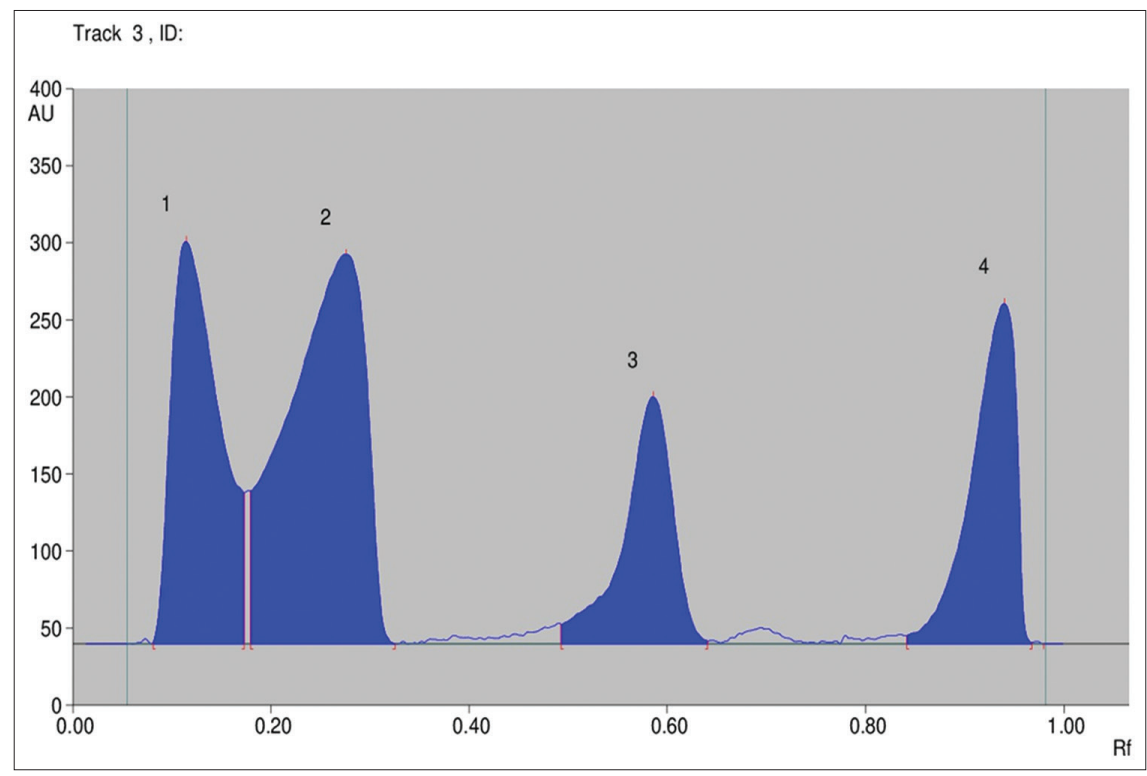

Fig. 5: High-performance thin-layer chromatography densitometric chromatogram of Sida glutinosa extract at $366 \mathrm{~nm}$

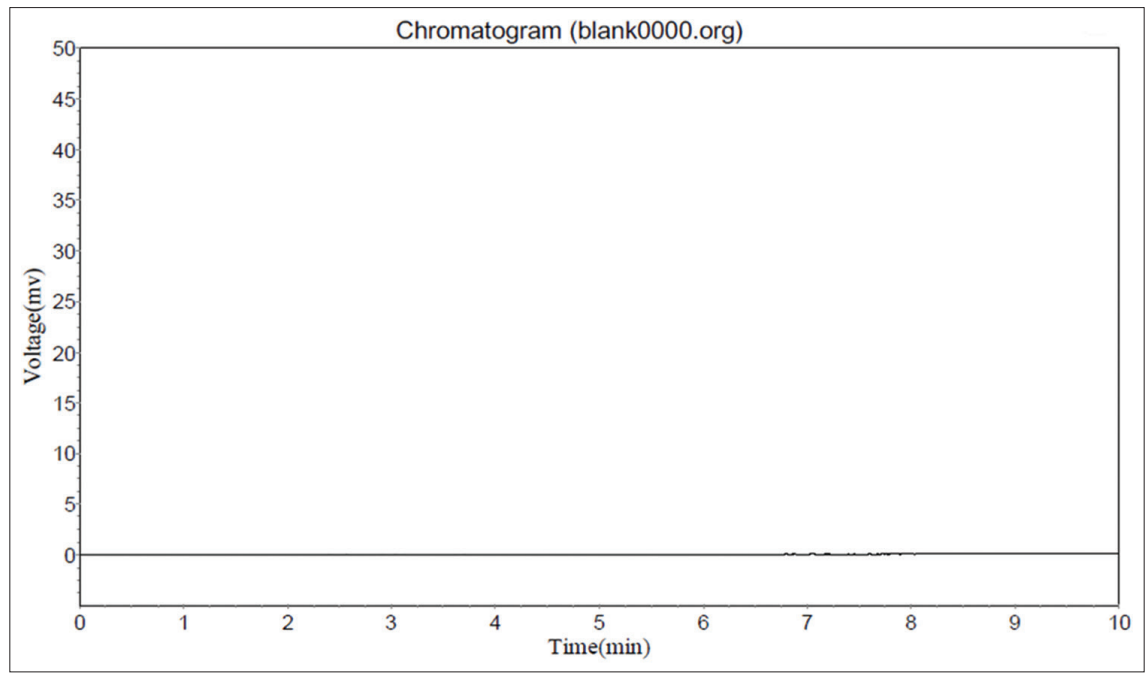

Fig. 6: Chromatogram for blank for alkaloid estimation

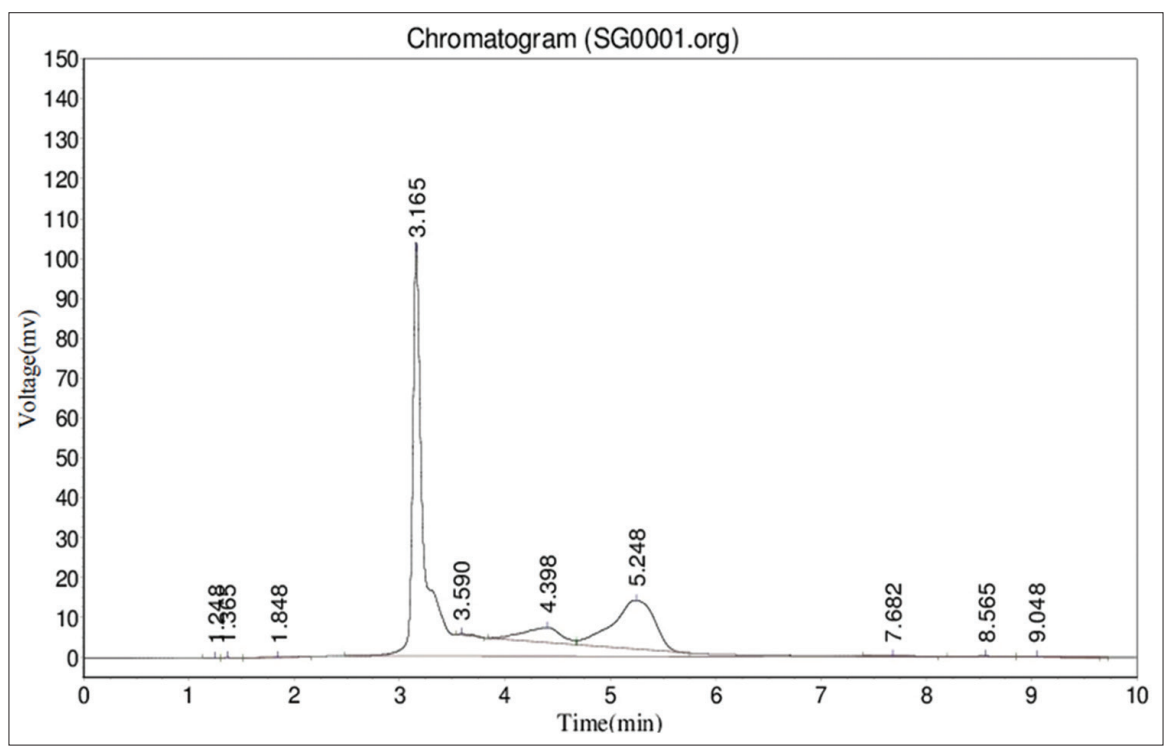

Fig. 7: Chromatogram of ethanolic extract of Sida glutinosa for alkaloid estimation 


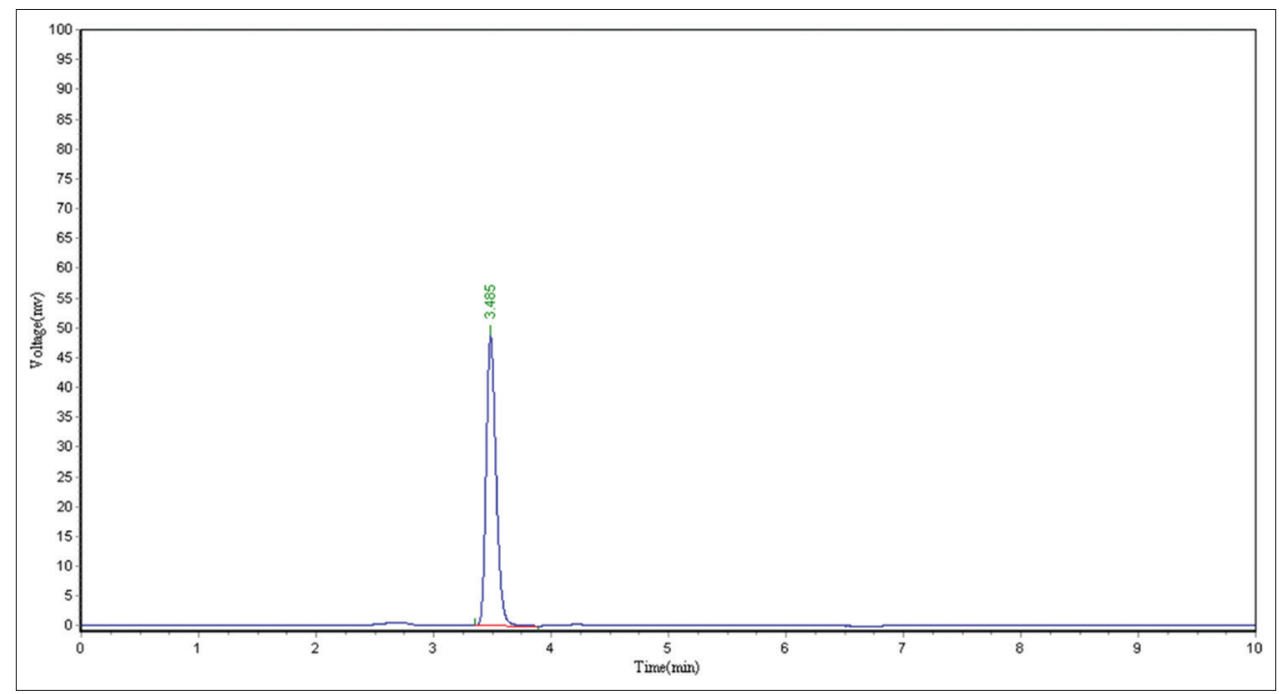

Fig. 8: Chromatogram of berberine standard for alkaloid estimation

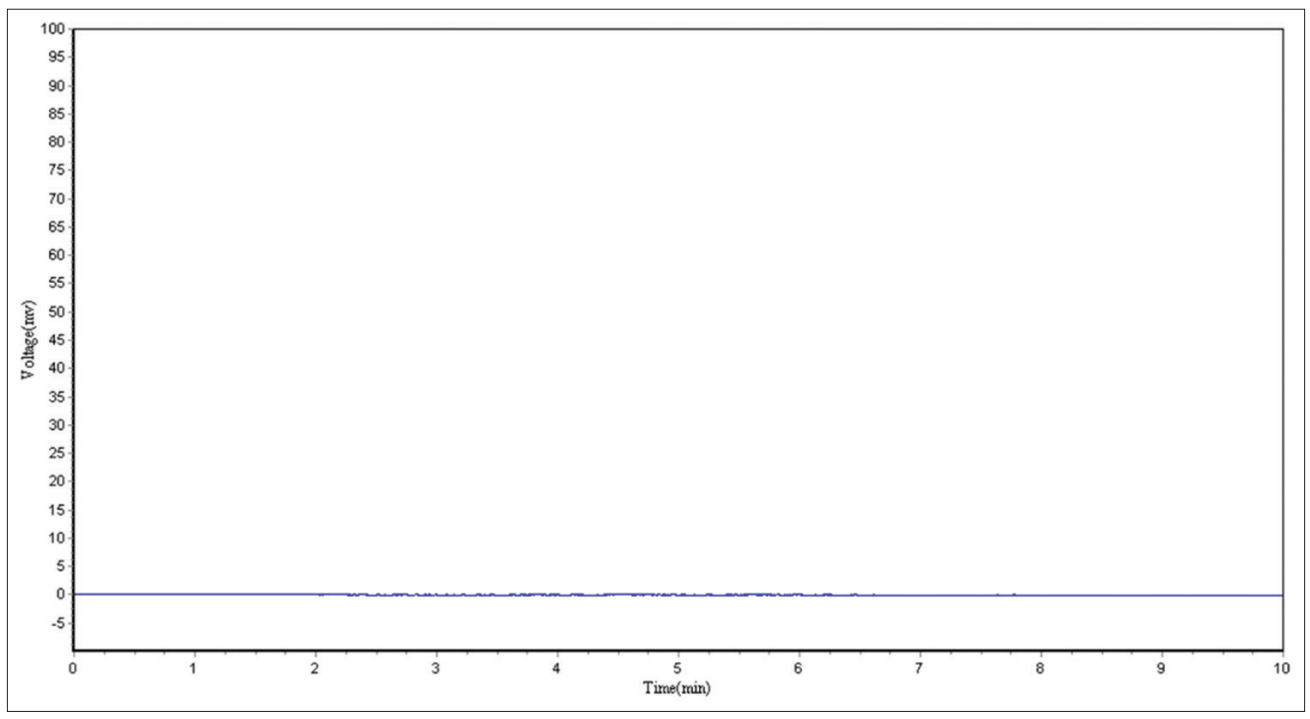

Fig. 9: Chromatogram for blank for flavonoids estimation

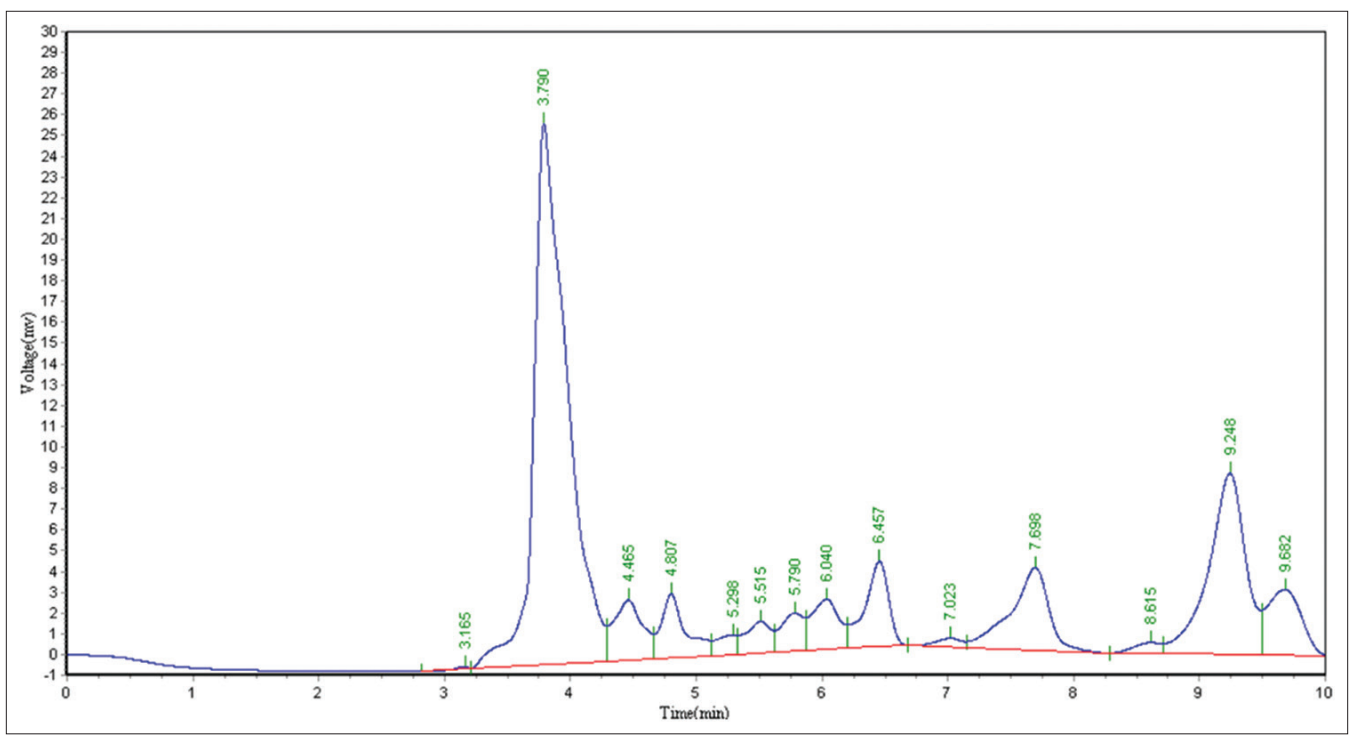

Fig. 10: Chromatogram for ethanolic extract of Sida glutinosa for flavonoids estimation 


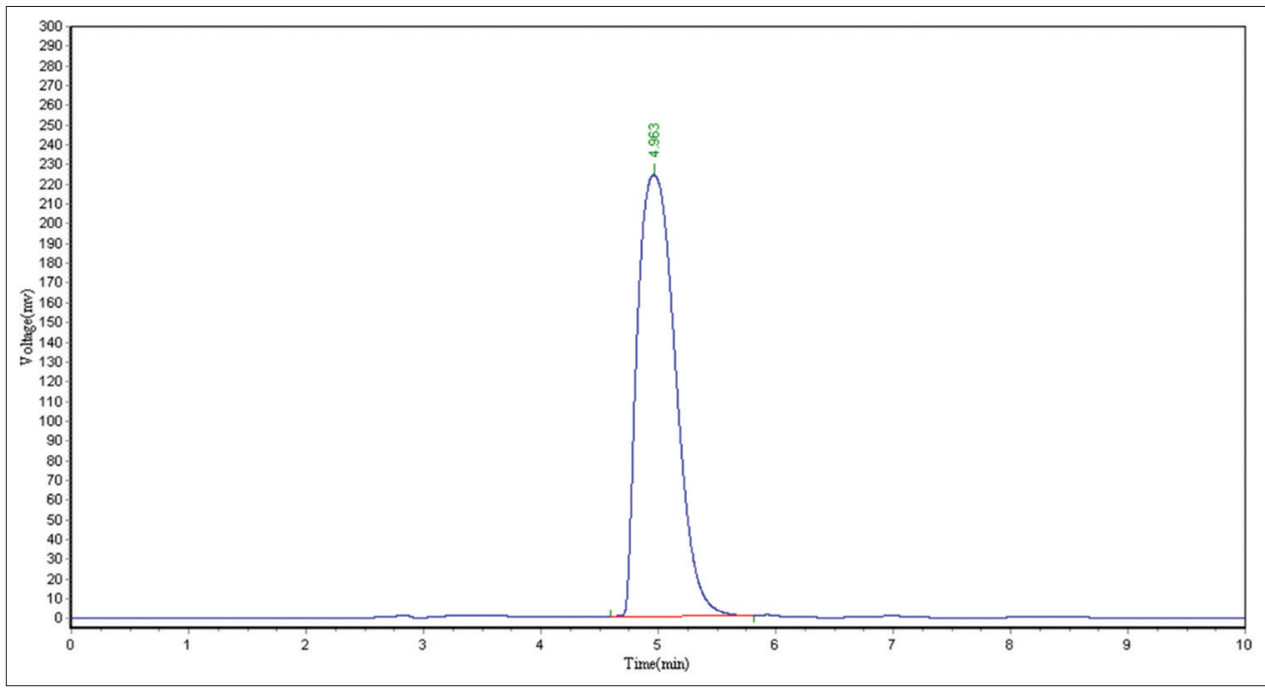

Fig. 11: Chromatogram of quercetin standard for flavonoid estimation

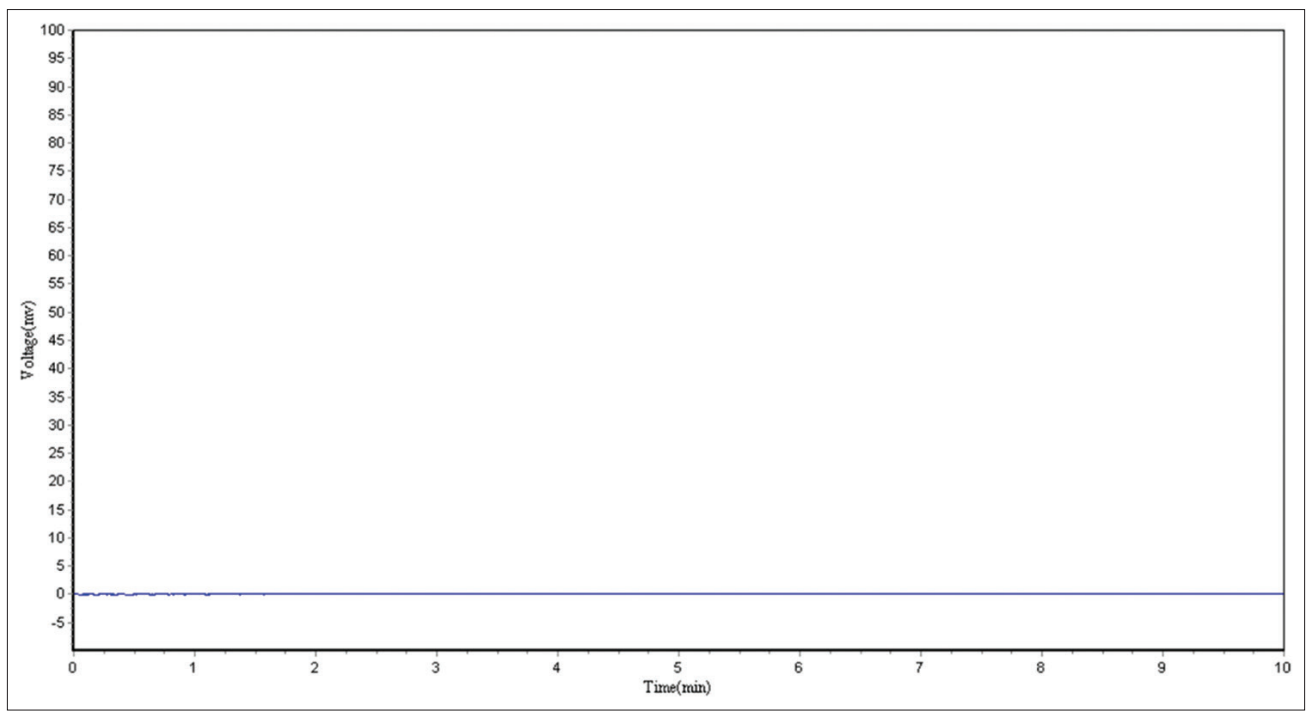

Fig. 12: Chromatogram for blank for phenolic estimation

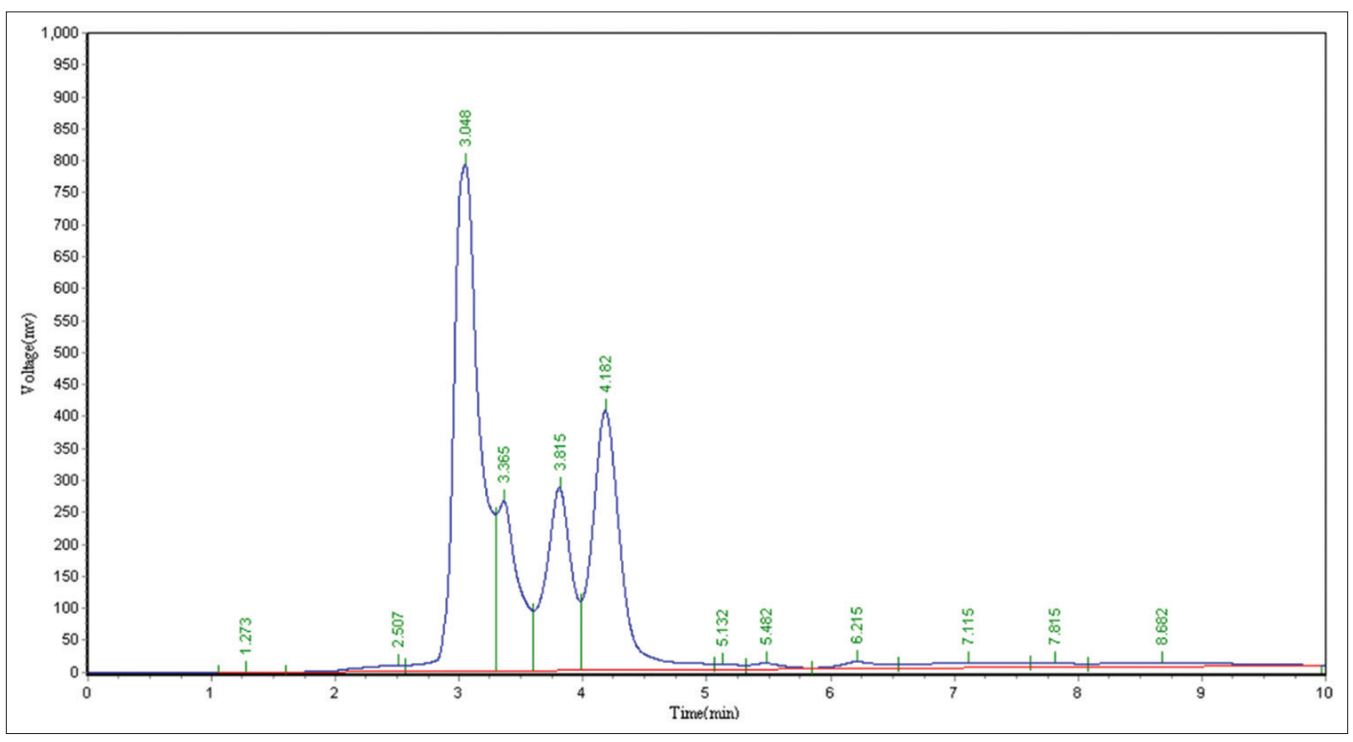

Fig. 13: Chromatogram for ethanolic extract of Sida glutinosa for phenolic estimation 


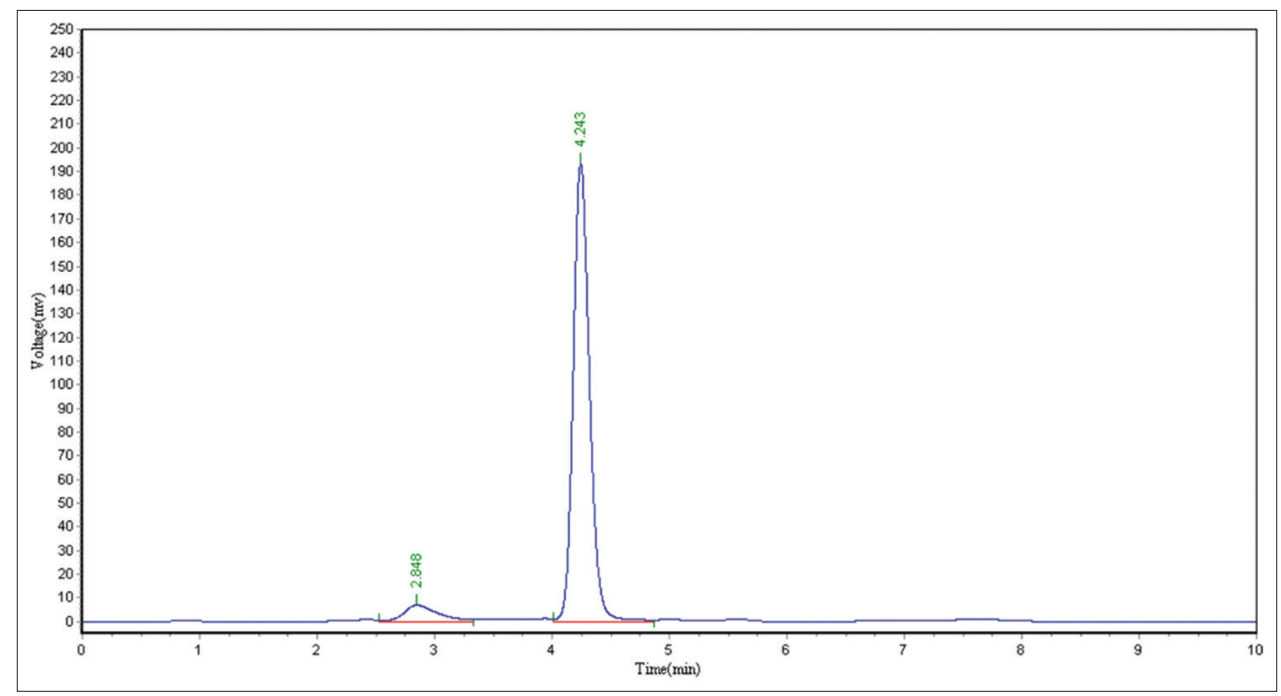

Fig. 14: Chromatogram for gallic acid standard for phenolic estimation

DPPH method at $1000 \mu \mathrm{g} / \mathrm{ml}$ of standard ascorbic acid is $98.19 \%$ and extract is $83.20 \%$, in nitric oxide model percentage of inhibition at $1000 \mu \mathrm{g} / \mathrm{ml}$ of standard ascorbic acid is $74.13 \%$ and extract is $70.66 \%$, and in hydroxyl radical assay percentage of inhibition at $1000 \mu \mathrm{g} / \mathrm{ml}$ of standard butylated hydroxyl toluene is $96.58 \%$ and extract is $75.68 \%$.

In HPTLC fingerprinting, the data will be collected and recorded based on the retardation factor. The resolution of the bands is mainly based on their physicochemical properties and their absorption maxima. Final outcome obtained is used to interpret and identify the quality and drug consistency by removing the adulterants and thereby authenticating the drug [23].

The main reason for phenolic compounds to behave as a lead principal compound is because it has a hydroxyl moiety which makes it a scavenging radical. The presence of total phenol crude ethanol extract was quantified with high precision using Rp-HPLC. The quantification of total phenolics is expressed in terms of equivalent weight of gallic acid as mg GAE/g of dry extract weight. Quantification of total phenolics in Sida rhombifolia has been reported as $56.25 \pm 0.83 \mathrm{mgGAE} / \mathrm{g}$ by Folin-Ciocalteu phenol UV spectrophotometric method [24] whereas for the $1^{\text {st }}$ time quantitative estimation of total phenolics in SG has been reported here which is $35.8 \pm 0.12 \mathrm{mgGAE} / \mathrm{g}$ using RP-HPLC. The literature reveals that the presence of flavonoids in the plant extract is responsible for the plant to become a potent medicinal plant. The presence of these constituents' reveals that the plant is of pharmacological importance, especially as anticancer, cardioprotective, and anti-inflammatory and thereby plays a key role in nutraceuticals [25]. Flavonoids present in the stem of Syzygium cumini are scavenging radicals, which are of pharmacological potent ones in treating heart diseases, inflammation, and also is an antioxidant [26]. In the present study, quantification of flavonoids in SG is reported significantly for the $1^{\text {st }}$ time by RP-HPLC which helps in the standardization of the drug. Alkaloids containing nitrogen moiety are one more category of phytoconstituents which are focused for treating various diseases [27]. There is no documentation of quantitative estimation of alkaloids in SG, and hence attempt is made here to quantify alkaloids by RP-HPLC. Therefore, it is evident that plants having important phytoconstituents such as phenolics, alkaloids, and flavonoids are potent molecule and are lead molecule for biological research which can act like lead molecules [28] and the quantification of these molecules helps in standardization of the drug.

\section{CONCLUSION}

SG is a potent medicinal plant and is rich in secondary phytoconstituents which play a key role in various pharmacological parameters. Qualitative and quantitative screening of phytoconstituents in SG concludes the presence of phenols, flavonoids, alkaloids, and other secondary metabolites which have a significant role to play in treating some diseases. Further investigation is being under progress for the isolation and characterization of novel phytoconstituents.

\section{ACKNOWLEDGMENTS}

I am sincerely thankful for my management to provide all the facilities for the work.

\section{AUTHORS' CONTRIBUTIONS}

All the authors have an equal contribution.

\section{CONFLICTS OF INTEREST}

There are no conflicts of interest.

\section{SOURCE OF FUNDING}

Self-funding.

\section{REFERENCES}

1. Deb DB. The Flora of Tripura State. New Delhi: Today \& Tomorrow's Printers and Publishers; 1981. p. 307.

2. Chopra RN, Nayar SL, Chopra IC. Glossary of Indian Medicinal Plants. New Delhi: PID, CSIR; 1992. p. 226.

3. Das N, Achari B, Harigaya Y, Dinda B. A new flavonol glucoside from the aerial parts of Sida glutinosa. J Asian Nat Prod Res 2011;13:965-71.

4. Das N, Nath J, Dinda B. Antioxidant phytochemicals from Sida glutinosa. J Pharm Res 2012;5:4845-8.

5. Das N, Saha T, Bhattacharjee S. A new biologically active ecdysteroid from the aerial parts of Sida glutinosa. J Pharmacogn Phytochem 2014;3:73-8

6. Khandelwal KR. Practical Pharmacognosy: Techniques and Experiments. $13^{\text {th }}$ ed. Pune: Nirali Prakashan; 2005, 149-156.

7. Government of India. Anonymous. Indian Pharmacopoeia. $2^{\text {nd }}$ ed. New Delhi: Government of India Publication; 1966. p. 367-70.

8. Kokate CK. Practical Pharmacognosy. $4^{\text {th }}$ ed. New Delhi: Vallabh Prakashan; 1994

9. Chase CR Jr., Pratt R. Fluorescence of powdered vegetable drugs with particular reference to development of a system of identification. J Am Pharm Assoc Am Pharm Assoc 1949;38:324-31.

10. Harbone JJ. Phytochemical Methods: A Guide to Modern Techniques of Plant Analysis. $2^{\text {nd }}$ ed. New York: Chapman and Hall; 1984. p. 85-4

11. Trease GE, Evans WC. Pharmacognosy. $13^{\text {th }}$ ed. New Delhi: ELBS Publication; 1989. p. 171.

12. Ohkawa H, Ohishi N, Yagi K. Assay for lipid peroxides in animal tissues by thiobarbituric acid reaction. Anal Biochem 1979;95:351-8.

13. Cuendet M, Hostettman K, Potterat O. Iridoid glucosides with free radical scavenging properties from Fagraea blume. Helv Chim Acta 
1997;80:1144-52.

14. Garrat DC. The quantitative analysis of drug Japan. Vol. 3. Japan: Chapman and Hall; 1964. p. 456-8.

15. Pathania V, Gupta AP, Singh B. Improved. HPTLC method for determination of curcuminoids from Curcuma longa. J Liq Chromatogr Relat Technol 2006;29:877-87.

16. Potawale SE, Pawar PD, Gabhe SY, Mahadik KR. A validated isocratic RP-HPLC method for concurrent estimation of gymnemagenin, gallic acid and glycyrrhetinic acid in polyherbal formulation. Int J Pharm Pharm Sci 2014;6:488-92.

17. Ang LF, Yam MF, Fung YT, Kiang PK, Darwin Y. HPLC method for simultaneous quantitative detection of quercetin and curcuminoids in traditional Chinese medicines. J Pharmacopuncture 2014;17:36-49.

18. Devaliya R, Shirsat M. Development and validation of RP-HPLC method for quantification of berberine in ethanol fraction of methanol extract and developed formulation of Tinospora Cordifolia. Orient $\mathrm{J}$ Chem 2017;33:989-94

19. Prasad M, Venugopal SP, Alagarsamy V, Sridevi C. Preliminary phytochemical analysis and oral acute toxicity study of stem bark of Syzygium cumini. Int J Pharm Pharm Sci 2016;8:209-13.

20. SenthilKumar RP, Bhuvaneshwari V, Malyaman V, RanjithKumar R, Sathiyavimal S. Phytochemical screening of aqueous leaf extract of Sida acuta Burm. F and its antibacterial activity. J Emerg Technol Innov Res 2018;5:474-8.

21. Murthy GP, Leelja BC, Ravishankar HG, Raj CG, Kumar R. Evaluation of neuroprotection and antioxidant activites via Drosophila model system in the active principle derived from Sida glutinosa comm. Ex Cav.-An aboriginal ethno-medicinal plant drug practiced in the folklore medicinal system. Biomed J Sci Tech Res 2018;11:8855-62.

22. Muneshwari P, Deepika S, Gopalakrishnan VK, Perumal PC, Poornima K. Phytochemical screening and free radical scavenging activity of chloroform extract of Sida acuta Burm. F. Int J Pharmacogn Phytochem Res 2016;8:663-7.

23. Shulammithi R, Sharanaya M, Tejaswini R, Kiranmai M. Standardization and quality evaluation of herbal drugs. J Pharm Biol Sci 2016;11:89-100

24. de Olidera AM, Pinheiro LS, Pereira CK, Matias WN, Gomes RA, Chaves OS, et.al. Total phenolic content and antioxidant activity of some Malvaceae species. Antioxidants 2012;1:33-43.

25. Hernandez-Rodriguez P, Baquero LP, Larrota HR. Flavonoids: Potential therapeutic agents by their antioxidant capacity. In: Health Benefits and Potential Applications. United Kingdom: Wood Head Publishing; 2019. p. $265-88$.

26. Gurung R. Preliminary phytochemical screening, total phenol and flavanoid content of Mimosa rubicaulis and Reinwardtia indica. Int $\mathrm{J}$ Pharm Pharm Sci 2020;12:54-8.

27. Ajanal M, Gundkalle MB, Nayak SU. Estimation of total alkaloid in chitrakadivati by UV-spectrophotometer. Anc Sci Life 2012;31:198-201.

28. Kumar S, Pandey AK. Chemistry and biological activities of flavonoids: An overview. ScientificWorldJournal 2013;2013:162750. 